\title{
PEMBERIAN MP-ASI DAN STATUS GIZI BAYI USIA 6-24 BULAN BERDASARKAN INDEKS BB/U DI DESA BAN KECAMATAN KUBU TAHUN 2014
}

\author{
Muhammad Akmal Hakim Bin Abdul Mutalib ${ }^{1}$ \\ ${ }^{1}$ Pendidikan Dokter, Fakultas Kedokteran Universitas Udayana \\ (muhammadakmalhakim91@gmail.com)
}

\begin{abstract}
ABSTRAK
Pemberian makanan pendamping ASI (MP-ASI) dini maupun terlambat akan menyebabkan bayi rentan mengalami penyakit infeksi, alergi, kekurangan gizi, dan kelebihan gizi, sehingga dapat menyebabkan malnutrisi dan gangguan pertumbuhan. Penelitian ini dilakukan untuk mengetahui gambaran pemberian MP-ASI dan status gizi bayi usia $6-24$ bulan di Desa Ban Kecamatan Kubu Karangasem.Penelitian ini merupakan penelitian potong lintang di Puskesmas Kubu II dengan jumlah sampel 81 orang yang dipilih secara convenient sampling. Sebagai sampel adalah bayi usia 6-24 bulan yang berdomisili di wilayah kerja Puskesmas Kubu Ildan tidak ada berkriteria eksklusi yaitu bayi dengan infeksi kronis, penyakit kronis, kelainan kongenital dan defek neurologis. Pengumpulan data dengan menggunakan kuisioner kepada orang tua sampel yang terpilih sebagai responden. Analisis data dilakukan secara univariate dan bivariate. Hasil penelitiandidapatkan dari 81 sampel didapatkan 59 sampel yang diberikan MP ASI tidak tepat waktu. Status gizi kurang ditemukan sebanyak 1 sampel dan 80 sampel dengan gizi baik. Dilihat dari tren tingkat pendidikan dan ketepatan pemberian MP ASI, semakin rendah tingkat penelitian semakin tidak tepat pemberian MP ASI. Dari kelompok ibu dengan tingkat pendidikan tinggi, 88.1\% memberikan MP ASI tidak tepat waktu. Dalam distribusi ketepatan pemberian MP ASI terhadap status gizi, pada pemberian MP ASI tidak tepat waktu ditemukan 1 kasus gizi kurang (1.7\%) dan 58 gizi baik (98.3). Sedangkan pada pemberian MP ASI tepat waktu ditemukan 22 kasus gizi baik (100\%).
\end{abstract}

Kata kunci: Makanan Pendamping ASI, Gizi Kurang, Gizi Baik.

\section{THE PROVISION OF COMPLEMENTARY FOOD AND NUTRITIONAL STATUS OF BABY AGE 6-24 MONTH BASED ON WEIGHT/AGE INDEX IN BAN VILLAGE, KUBU DISTRICT}

\section{ABSTRACT}

The provision of complementary foods (solids) early or too late will cause the baby susceptible to infectious diseases, allergies, nutritional deficiencies, and excess nutrients, which can lead to malnutrition and impaired growth. This research is to know the description the provision of complementary feeding and nutritional status of infants aged 6-24 months. This study was a cross sectional study in Public Healthcare Centre (Puskesmas) Kubu II with a sample of 81 people were selected by convenient sampling. As the sample is domiciled in infants Puskesmas Kubu II, and the exclusion criteria are infants with chronic infections, chronic diseases, congenital abnormalities and neurological defects. Data collection using questionnaires to a sample of parents selected as responders and weight measurements of the samples. Data analysis was performed univariate and bivariate. The 
result is from 81 samples obtained 59 samples were not given timely complementary feeding. Malnutrition status was found in 1 sample and 80 samples with good nutrition. Judging from the trend level of education and the provision of complementary feeding accuracy, the lower the level of research increasingly imprecise provision of complementary feeding. From the group of mothers with a high education level, $88.1 \%$ did not provide timely complementary feeding. In granting the accuracy of the distribution of complementary feeding on the nutritional status, the provision of timely complementary feeding not found one case of malnutrition (1.7\%) and 58 well-nourished (98.3). While the provision of timely complementary feeding found 22 cases of good nutrition (100\%).

Keywords: breast milk complementary feeding, bad nutrition, good nutrition

\section{PENDAHULUAN}

Makanan yang terbaik untuk bayi usia 0-6 bulan adalah ASI. Air Susu Ibu (ASI) merupakan sumber energi terbaik dan paling ideal dengan komposisi yang seimbang sesuai dengan kebutuhan bayi pada masa pertumbuhan. Manfaat pemberian ASI tidak hanya dirasakan oleh bayi tetapi juga oleh ibu, lingkungan bahkan negara. Pemberian ASI ini diberikan sampai bayi berusia 6 bulan, setelah 6 bulan harus mulai diperkenalkan dengan makanan padat, dan ASI masih tetap diberikan hingga bayi berusia 2 tahun. ${ }^{1}$ Pada usia 6 bulan kebutuhan bayi akan zat gizi makin bertambah karena seiring dengan pertumbuhan dan perkembangan bayi, sedangkan produksi ASI mulai menurun, sehingga bayi sangat memerlukan makanan tambahan sebagai pendamping ASI. ${ }^{2}$

Setelah 6 bulan pemberian ASI saja tidak cukup untuk memenuhi seluruh kebutuhan makanan bayi, ASI hanya akan memenuhi sekitar 60-70\% kebutuhan bayi, sedangkan yang $30-40 \%$ harus dipenuhi dari makanan pendamping atau makanan tambahan. Makanan pendamping ASI adalah makanan atau minuman tambahan yang mengandung zat gizi, yang diberikan kepada bayi atau anak usia 6- 24 untuk memenuhi kebutuhan gizi selain dari ASI. ${ }^{3}$ Sementara itu pemberian makanan tambahan yang tidak tepat dalam kualitas dan kuantitasnya dapat menyebabkan bayi menderita gizi kurang. ${ }^{4}$ Pada bayi dan anak kekurangan gizi akan menimbulkan gangguan pertumbuhan dan perkembangan yang apabila tidak di atasi secara dini dapat berlanjut hingga dewasa. Usia 0-24 bulan merupakan masa pertumbuhan dan perkembangan yang pesat, sehingga kerap diistilahkan sebagai periode emas sekaligus periode kritis, periode emas dapat terwujudkan apabila pada masa ini bayi dan anak memeperoleh asupan gizi yang sesuai untuk tumbuh kembang anak yang optimal. Sebaliknya apabila bayi dan anak pada masa ini memperoleh makanan yang tidak sesuai kebutuhan gizinya, maka periode emas akan berubah menjadi periode kritis yang akan mengganggu tumbuh kembang bayi dan anak, baik pada masa ini maupun masa selanjutnya. ${ }^{3}$

World Health Organization (WHO) merekomendasikan para ibu untuk menyusui secara eksklusif selama 6 bulan, melanjutkan dengan memberikan makanan pendamping ASI dari bahanbahan lokal yang kaya nutrisi sambil tetap memberikan ASI sampai anak berusia 2 tahun. Berdasarkan hasil Survei Sosial Ekonomi Nasional (Susenas) (2002) terdapat banyak ibu yang memberikan makanan terlalu dini kepada bayinya, yaitu $32 \%$ ibu yang memberikan makanan tambahan kepada bayi yang berumur 2- 3 bulan, seperti bubur, nasi, dan pisang, sedangkan $69 \%$ adalah pada bayi usia 4-5 bulan. Kemudian penelitian yang dilakukan oleh Irawati (2007) di Pusat Pelatihan dan Pengembangan Gizi dan Makanan Departemen Kesehatan, diperoleh hasil bahwa lebih dari $50 \%$ bayi di Indonesia telah mendapat makanan pendamping ASI dengan usia kurang dari 1 bulan. Menurut Susanty dkk (2012) pemberian makanan pendamping ASI yang terlalu dini dapat menimbulkan gangguan pada pencernaan seperti seperti diare. Sebaliknya pemberian makanan yang 
terlalu lambat mengakibatkan bayi mengalami kesulitan belajar mengunyah, tidak menyukai makanan padat, dan bayi kekurangan gizi. ${ }^{5}$

Selain itu, kaitan penyakit infeksi dengan keadaan kurang gizi merupakan hubungan timbal balik yaitu hubungan sebab akibat. Penyakit infeksi dapat memperburuk kedaan gizi, dan keadaan gizi yang jelek dapat mempermudah terkena infeksi, penyakit yang umumnya terkait dengan masalah gizi antara lain adalah diare. Penyakit diare merupakan salah satu penyebab kematian sebesar $15-34 \%$ dari semua penyebab kematian pada balita, selain itu diare juga penyebab gizi kurang.

Berdasarkan data yang diperoleh dari Dinas Kesehatan Provinsi Bali, angka pemberian ASI Ekslusif di kabupaten Karangasem tahun 2012 merupakan yang terendah di seluruh Bali dengan nilai 58,59\%. ${ }^{6}$ Selain itu, data dari Puskesmas Kubu II Karangasem didapatkan keberhasilan program ASI eksklusif tahun 2013 hanya mencapai 61,45\%, masih dibawah target yakni $80 \%$. Namun berdasarkan hasil wawancara dengan salah satu petugas puskesmas, diperkirakan saat ini tingkat pemberian ASI eksklusif hanya sekitar $20 \%$ saja. Diakui bahwa pencapaian $61,45 \%$ pada data terdahulu kemungkinan tidak valid hingga saat ini. Berdasarkan data yang didapatkan di Puskesmas Kubu II, sejumlah 2.606 balita yang ditimbang pada bulan April 2014 didapatkan gizi kurang 92 balita, gizi buruk 17 balita, dan gizi baik 2.497 balita. Hal ini menunjukkan tren yang fluktuatif dimana pada tahun 2012, dengan jumlah balita yang ditimbang sebanyak 2749 ditemukan 12 balita dengan gizi buruk dan 89 balita dengan gizi kurang. Sedangkan pada tahun 2013 dari 2671 balita ditemukan 18 balita gizi buruk dan 130 balita gizi kurang.

Berdasarkan pengamatan peneliti masih banyak ditemukan ibu yang memberikan makanan pendamping ASI di usia dini, faktor yang berpengaruh antara lain pendidikan ibu yang rendah, ketidakhadiran ibu di rumah karena bekerja, sosial budaya serta iklan susu formula yang gencar. Banyak dari ibu memberikan MP-ASI dini dikarenakan turunan dari orang tuanya terdahulu, baik dikarenakan kurangnya pengetahuan tentang asi eksklusif maupun kepercayaan di masyarakat. Banyak ibu yang merasa bayi mereka tidak ada masalah bila diberikan makanan pendamping dari umur 2 bulan.

Dari uraian dan data di atas menunjukan jika pemberian MP-ASI tidak tepat dalam kualitas dan kuantitas dapat menyebabkan bayi menderita kurang gizi, pemberian yang terlalu dini juga dapat menyebabakan gangguan pencernaan seperti diare. Berdasarkan hal tersebut maka peneliti melakukan penelitian tentang pemberian makanan pendamping ASI dan status gizi pada anak usia 6-24 bulan di desa ban, wilayah kerja Puskesmas Kubu II Karangasem.

\section{METODE PENELITIAN}

Penelitian ini menggunakan teknik penelitian deskriptif dengan rancangan cross sectional. Dilakukan di Posyandu yang berada dalam di Desa Ban wilayah kerja Puskesmas Kubu II, Kecamatan Kubu Kabupaten Karangasem pada Bulan Junitahun 2014.

Populasi target dalam penelitian ini adalah seluruh ibu yang memiliki anak bayi berusia 6-24 bulandi Kabupaten Karangasem. Populasi terjangkau dalam penelitian ini adalah populasi target yang tercatat di register posyandudi Desa Ban wilayah kerja Puskesmas Kubu II Karangasem tahun 2014.

Sampel dalam penelitian ini adalah bayi berusia 6-24 bulan yang berkunjung untuk berobat/imunisasi di Puskesmas dan Posyandu yang berada dalam wilayah kerja Puskesmas Kubu II Kabupaten Karangasem pada bulan Juni 2014, dengan Kriteria inklusi penelitian ini antara lain: bayi berusia 6-24 bulan berdomisili di Kecamatan Kubu, bayi lahir spontan pervaginam, aterm (37-42 minggu), bayi yang orang tuanya bersedia menjadikan sampel dan mendapat persetujuan dari orang tua. Kriteria eksklusi antara lain: orang tua yang tidak bersedia atau menolak untuk menjadi responden.Bayi dengan infeksi kronis, penyakit kronis, kelainan kongenital, dan defek neurologis. Berdasarkan perhitungan rumus peneliti menetapkan sampel sebanyak 81 orang.

Responden pada pengambilan sampel ini adalah ibu bayi yang datang untuk berobat/imunisasi 
di Puskesmas dan Posyandu yang berada dalam wilayah kerja Puskesmas Kubu II

Variabel penelitian ini terdiri dari: umur, jenis kelamin, tingkat pendidikan, pekerjaan, status gizi, pengetahuan tentang asi eksklusif dan usia pertama pemberian MP ASI.Instrumen penelitian yang dipergunakan dalam penelitian ini berupa kuesioner dan pengukuran berat badan.

Data diperoleh secara primer dengan cara melakukan pengukuran berat badan bayi dan wawancara langsung terhadap sampel berdasarkan kuesioner yang telah dipersiapkan.Analisis data dilakukan secara deskriptif. Penyajian data berupa tabulasi dari kuesioner survei dan dijabarkan menggunakan tabel kemudian dijelaskan secara naratif.

\section{HASIL}

\section{KarakteristikResponden}

Penelitian dilakukan terhadap 81 sampel responden yang bertempat tinggal di Banjar Ban, Banjar Buluh, Banjar Belong, Banjar Cutcut Mangun Bumi, dan Banjar Dukuh Tangeban, Desa Ban, kecamatan Kubu, Kabupaten Karangasem. Dari sejumlah responden yang terpilih seluruhnya menyatakan bersedia untuk ikut dalam penelitian ini.

$$
\text { Pengumpulan data dilaksanakan pada }
$$
tanggal 17 Juni hingga 25 Juni 2014. Wawancara dilakukan oleh dua orang mahasiswa dan dilakukan pada saat posyandu dilakukan di banjar tersebut. Dari 81 responden yang diwawancarai dan subjek yang di lakukan pengukuran, diperoleh karakteristik sampel meliputi usia, jenis kelamin, pendidikan, dan pekerjaan.

Dari hasil penelitian, kelompok umur ibu yang paling banyak adalah kelompok usia 20-25 tahun yakni sebanyak 29 ibu (35.8\%). Didapatkan juga kategori pendidikan paling banyak pada responden adalah pendidikan rendah, yakni dari tidak sekolah hingga tamat SD sebanyak 59 orang (72.8\%).

Dari sebaran pekerjaan, petani merupakan mayoritas mata pencaharian responden yakni 33 orang (40.7\%). Data tentang sebaran karakteristik responden dapat dilihat pada tabel 1.

Tabel1. Karakteristik Responden

\begin{tabular}{llll}
\hline \multirow{2}{*}{ Karakteristik Responden } & $\begin{array}{l}\text { Jumlah } \\
\text { Umur }\end{array}$ & (N) & $\begin{array}{l}\text { Persentase } \\
\text { (\%) }\end{array}$ \\
\hline 20-25 Tahun & 1 & $1.2 \%$ \\
& $26-30$ Tahun & 26 & $35.8 \%$ \\
& 31-35 Tahun & 21 & $32.1 \%$ \\
& $>35$ Tahun & 4 & $25.9 \%$ \\
Tingkat & Total & 81 & $4.9 \%$ \\
pendidikan & Pendidikan Rendah & 59 & $100 \%$ \\
& Pendidikan Menengah & 16 & $72.8 \%$ \\
& Pendidikan Tinggi & 6 & $19.8 \%$ \\
& Total & 81 & $7.4 \%$ \\
\hline Pekerjaan & Pegawai Negeri Sipil & 1 & $100 \%$ \\
& Pegawai Swasta & 9 & $1.2 \%$ \\
& Guru & 5 & $11.1 \%$ \\
& Pedagang & 7 & $6.2 \%$ \\
& Petani & 33 & $8.6 \%$ \\
& Buruh & 14 & $40.7 \%$ \\
& Lainnya & 6 & $17.3 \%$ \\
& & $7.4 \%$
\end{tabular}




$\begin{array}{lll}\text { Tidak Bekerja } & 6 & 7.4 \% \\ \text { Total } & 81 & 100 \%\end{array}$

Tabel 2. Karakteristik Sampel

\begin{tabular}{llll}
\hline Karakteristik Sampel & & $\begin{array}{l}\text { Jumlah } \\
\text { (N) }\end{array}$ & $\begin{array}{l}\text { Persentase } \\
\text { (\%) }\end{array}$ \\
\hline Kelompok Usia & 6-12 Bulan & 43 & $53.1 \%$ \\
& 13-24 Bulan & 38 & $46.9 \%$ \\
& Total & 81 & $100 \%$ \\
\hline Jenis Kelamin & Laki-Laki & 41 & $50.6 \%$ \\
& Perempuan & 40 & $49.4 \%$ \\
& Total & 81 & $100 \%$ \\
\hline
\end{tabular}

\section{Karakteristik Sampel}

Usia bayi yang ikut dalam penelitian ini mulai dari usia 6 bulan hingga 24 bulan dengan rerata usia 12.46 bulan dan simpang baku 5.184 . Kelompok usia yang paling banyak dalam penelitian ini adalah kelompok usia 6-12 Bulan dengan jumlah 43 orang $(53.1 \%)$ dan paling sedikit adalah kelompok usia 13-24 Bulan sebanyak 38 bayi (46.9\%). Jenis kelamin sampel yang paling banyak merupakan laki laki sebanyak 41 bayi (50.6\%). Data tentang karakteristik sampel dapat dilihat pada tabel 2.

\section{Distribusi Status Gizi Bayi}

Setelah dilakukan pengukuran berat badan bayi, rata-rata berat badan bayi adalah $9.031 \mathrm{~kg}$ dengan standar deviasi 1.4671. Berat badan paling rendah adalah $6.7 \mathrm{~kg}$, tertinggi $13.0 \mathrm{~kg}$, dan terbanyak adalah $8.6 \mathrm{~kg}$. Dalam penelitian ini didapatkan hasil perhitungan status gizi berdasarkan berat badan terhadap umur diketahui sebagian besar bayi dalam penelitian ini berstatus gizi baik, yakni sebanyak 80 anak (98.8\%). Sebaran status gizi bayi dalam penelitian ini dapat dilihat pada tabel 5.3.

\section{Distribusi Pengetahuan Ibu tentang ASI Eksklusif}

Dari 81 responden yang keseluruhannya

adalah ibu dari sampel, sebanyak 30 orang menyatakan pernah mendengar istilah ASI Eksklusif, dan 51 tidak pernah mendengar. Dari 30 sampel yang pernah mendengar, paling banyak mendapat informasi dari dokter atau bidan sebanyak 21 orang (77.8\%). Sedangkan sampel yang menjawab pengertian ASI Eksklusif secara benar adalah 25 orang (30.9\%). Data tentang distribusi pengetahuan ibu tentang ASI eksklusif dapat dilihat pada tabel 4.

Distribusi Usia Pertama Pemberian MP ASI, ketepatan pemberian MP ASI, Jenis MP ASI, dan Frekuensi pemberian MP ASI.

Dalam penelitian ini, paling banyak ibu memberikan MP ASI pertama kali pada usia 6 bulan sebanyak 22 ibu (27.2\%). Berdasarkan jenis, sebagian besar bayi mendapatkan bubur susu sebagai makanan pertama mereka yakni 72 anak (88.9\%).

Pada saat penelitian didapatkan 59 bayi yang diberikan MP ASI tidak tepat waktu, yakni dari usia 1 hingga 5 bulan sebanyak 59 bayi (72.8\%). Frekuensi pemberian MP ASI paling banyak diberikan 3 kali sehari sebanyak 67 bayi (82.7\%). Data tentang sebaran pemberian MP ASI berdasarkan usia, jenis, dan frekuensi dapat dilihat pada tabel 5 .

Tabel 3. Distribusi Status Gizi Bayi

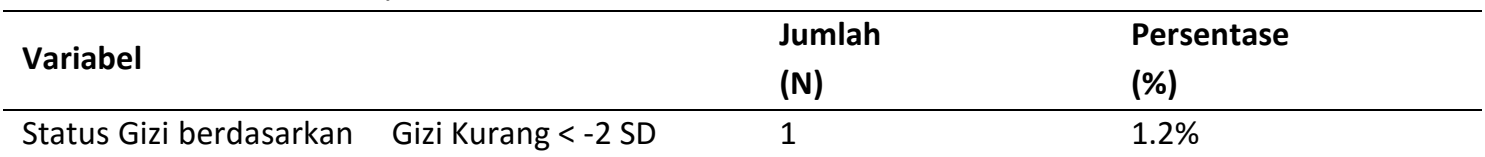


ISSN: 2089-9084

ISM, VOL. 4 NO.1, SEPTEMBER-DESEMBER, HAL 14-23

$\mathrm{BB} / \mathrm{U}$

Gizi Baik $\geq-2$ SD

80

$98.8 \%$

Total

81

$100 \%$

Tabel 4. Distribusi Pengetahuan Ibu tentang ASI Eksklusif

\begin{tabular}{|c|c|c|c|}
\hline Variabel & & Jumlah(N) & Persentase(\%) \\
\hline Pernah Mendengar & $\mathrm{Ya}$ & 30 & $37 \%$ \\
\hline \multirow[t]{2}{*}{ tentang ASI Eksklusif } & Tidak & 51 & $63 \%$ \\
\hline & Total & 81 & $100 \%$ \\
\hline Sumber Informasi (n & Dokter/Bidan & 21 & $77.8 \%$ \\
\hline \multirow[t]{3}{*}{$=30)$} & Petugas Puskesmas & 7 & $18.5 \%$ \\
\hline & Lainnya & 2 & $3.7 \%$ \\
\hline & Total & 30 & $100 \%$ \\
\hline Pengertian & Benar & 25 & $30.9 \%$ \\
\hline \multirow[t]{2}{*}{ Eksklusif } & Salah & 56 & $69.1 \%$ \\
\hline & Total & 81 & $100 \%$ \\
\hline
\end{tabular}

Tabel 5.Distribusi Usia Pertama Pemberian Makanan Pendamping ASI, ketepatan pemberian MP ASI, Jenis MP ASI, dan Frekuensi pemberian MP ASI.

\begin{tabular}{|c|c|c|c|}
\hline Variabel & & Jumlah(N) & Persentase(\%) \\
\hline Pertama & 1 Bulan & 6 & $7.4 \%$ \\
\hline Pemberian Makanan & 2 Bulan & 7 & $8.6 \%$ \\
\hline \multirow[t]{5}{*}{ Pendamping ASI } & 3 Bulan & 21 & $25.9 \%$ \\
\hline & 4 Bulan & 20 & $24.7 \%$ \\
\hline & 5 Bulan & 5 & $6.2 \%$ \\
\hline & 6 Bulan & 22 & $27.2 \%$ \\
\hline & Total & 81 & $100 \%$ \\
\hline Ketepatan & Tepat Waktu & 22 & $27.2 \%$ \\
\hline \multirow[t]{2}{*}{ Pemberian MP-ASI } & Tidak Tepat Waktu & 59 & $72.8 \%$ \\
\hline & Total & 81 & $100 \%$ \\
\hline Jenis Makanan & Susu Formula & 8 & $9.9 \%$ \\
\hline \multirow[t]{5}{*}{ Pendamping ASI } & Air Tajin & 4 & $4.9 \%$ \\
\hline & Pisang & 62 & $76.5 \%$ \\
\hline & Bubur Susu & 72 & $88.9 \%$ \\
\hline & Nasi Putih & 12 & $14.8 \%$ \\
\hline & Lainnya & 25 & $30.9 \%$ \\
\hline Frekuensi Pemberian & 2 Kali & 4 & $4.9 \%$ \\
\hline \multirow[t]{3}{*}{ MP ASI Saat ini } & 3 Kali & 67 & $82.7 \%$ \\
\hline & 4 Kali & 10 & $12.3 \%$ \\
\hline & Total & 81 & $100 \%$ \\
\hline
\end{tabular}

Distribusi Alasan Pemberian Jenis MP ASI Pertama Kali dan Alasan Pemberian MP ASI Tidak Tepat Waktu
Alasan yang paling banyak untuk pemberian jenis MP ASI pertama kali yang diberikan ibu kepada bayinya adalah mudah diperoleh/praktis sebanyak 50 ibu (61.7\%). Sedangkan distribusi alasan

19 
pemberian MP ASI tidak tepat waktu didominasi oleh karena tidak tau kapan seharusnya MP ASI diberikan, yakni sebanyak 54 ibu (91.5\%). Data tentang distribusi alasan pemberian jenis MP ASI pertama kali dan alasan pemberian MP ASI tidak tepat waktu dapat dilihat pada tabel 6 .

Tabel 6. Distribusi Alasan Pemberian Jenis MP ASI Pertama Kali dan Distribusi Alasan Pemberian MP ASI Tidak Tepat Waktu

\begin{tabular}{|c|c|c|c|}
\hline \multicolumn{2}{|l|}{ Variabel } & $\begin{array}{l}\text { Jumlah } \\
\text { (N) }\end{array}$ & $\begin{array}{l}\text { Persentase } \\
\text { (\%) }\end{array}$ \\
\hline & $\begin{array}{l}\text { Lengkap Kandungan } \\
\text { Gizi }\end{array}$ & 12 & $14.8 \%$ \\
\hline Pemberian & Murah / Hemat & 19 & $23.5 \%$ \\
\hline Jenis $\quad M P \quad A S I$ & Rasa & 0 & $0 \%$ \\
\hline \multirow[t]{2}{*}{ Pertama Kali } & $\begin{array}{l}\text { Mudah Diperoleh / } \\
\text { Praktis }\end{array}$ & 50 & $61.7 \%$ \\
\hline & Total & 81 & $100 \%$ \\
\hline \multirow{5}{*}{$\begin{array}{l}\text { Distribusi Alasan } \\
\text { Pemberian MP ASI } \\
\text { Tidak Tepat Waktu } \\
(\mathrm{n}=59)\end{array}$} & $\begin{array}{l}\text { Tidak Tau Kapan MP } \\
\text { ASI Seharusnya } \\
\text { diberikan }\end{array}$ & 54 & $91.5 \%$ \\
\hline & Budaya Lokal & 43 & $72.9 \%$ \\
\hline & $\begin{array}{l}\text { Bayi Selalu Merasa } \\
\text { Lapar Jika Hanya } \\
\text { diberikan ASI }\end{array}$ & 10 & $16.9 \%$ \\
\hline & Sibuk Bekerja & 5 & $8.5 \%$ \\
\hline & ASI Tidak Keluar & 4 & $6.8 \%$ \\
\hline
\end{tabular}

\section{Distribusi Tingkat Pendidikan Terhadap Ketepatan}

\section{Pemberian MP ASI}

Pada penelitian ini, didapatkan hasil tabulasi silang antara tingkat pendidikan terhadap ketepatan waktu pemberian MP ASI adalah pada ibu yang mendapatkan pendidikan tingkat rendah, sebanyak 52 ibu memberikan MP ASI tidak tepat waktu (88.1\%) dan tepat waktu sebanyak 7 ibu (11.9\%).Pada ketegori tingkat pendidikan menengah, sebanyak 6 ibu memberikan MP ASI tidak tepat waktu (37.5\%) dan 10 ibu memberikan MP ASI tepat waktu (62.5\%). Sedangkan ibu dengan tingkat pendidikan tinggi, 1 orang memberikan MP ASI tidak tepat waktu (16.7\%) dan 5 orang lainnya memberikan MP ASI tepat waktu (83.3\%). Dari data diatas dapat dilihat tren dari tingkat pendidikan terhadapat ketepatan waktu pemberian MP ASI adalah semakin rendah tingkat pendidikan, semakin tidak tepat waktu pemberian MP ASI. Sebaliknya semakin tinggi tingkat pendidikan, semakin tepat waktu pemberian MP ASI. Distribusi data tentang tingkat pendidikan terhadap ketepatan pemberian MP ASI dapat dilihat pada tabel 7 .

Tabel 7. Distribusi Tingkat Pendidikan Terhadap Ketepatan Pemberian MP ASI

\begin{tabular}{|c|c|c|c|c|c|c|c|c|}
\hline & & Ketepa & an Pem & erian & P ASI & & & \\
\hline & & Tidak & Tepat & $\%$ & Tepat & $\%$ & Total & $\%$ \\
\hline & & Waktu & & & Waktu & & & \\
\hline & Pendidikan & 52 & & 88.1 & 7 & 11.9 & 59 & $100 \%$ \\
\hline Dendidikan & Rendah & & & $\%$ & & $\%$ & & \\
\hline Penaiaikan & Pendidikan & 6 & & 37.5 & 10 & 62.5 & 16 & $100 \%$ \\
\hline
\end{tabular}




\begin{tabular}{|c|c|c|c|c|c|c|}
\hline Menengah & & $\%$ & & $\%$ & & \\
\hline Pendidikan & 1 & 16.7 & 5 & 83.3 & 6 & $100 \%$ \\
\hline Tinggi & & $\%$ & & $\%$ & & \\
\hline
\end{tabular}

Tabel 8. Distribusi Ketepatan Pemberian MP ASI Terhadap Status Gizi Bayi

\begin{tabular}{|c|c|c|c|c|c|c|c|c|}
\hline & & & \multicolumn{4}{|l|}{ Status Gizi Bayi } & \multirow[b]{2}{*}{ Total } & \multirow[b]{2}{*}{$\%$} \\
\hline & & & $\begin{array}{l}\text { Gizi Kurang ( > } \\
-2 \text { SD) }\end{array}$ & $\%$ & $\begin{array}{l}\text { Gizi Baik ( } \geq- \\
2 \mathrm{SD})\end{array}$ & $\%$ & & \\
\hline \multirow{3}{*}{$\begin{array}{l}\text { Ketepatan } \\
\text { Pemberian } \\
\text { ASI }\end{array}$} & \multirow{3}{*}{ MP } & Tepat & 1 & 1.7 & 58 & $98.3 \%$ & 59 & $100 \%$ \\
\hline & & Waktu & & $\%$ & & & & \\
\hline & & Tepat Waktu & 0 & $0 \%$ & 22 & $100 \%$ & 22 & $100 \%$ \\
\hline
\end{tabular}

\section{Distribusi Ketepatan Pemberian MP ASI Terhadap Status Gizi Bayi}

Berdasarkan distribusi ketepatan waktu pemberian MP ASI terhadap status gizi bayi berdasarkan indeks berat badan terhadap umur, didapatkan hasil bahwa pada pemberian MP ASI tidak tepat waktu, ditemukan 1 bayi yang mengalami gizi kurang (1.7\%), dan 58 bayi lainnya mendapatkan gizi baik (98.3\%). Sedangkan pada pemberian MP ASI tepat waktu didapatkan 22 bayi gizi baik (100\%) dan tidak ada bayi dengan gizi kurang. Data tentang distribusi ketepatan pemberian MP ASI terhadap status gizi bayi dapat dilihat pada tabel 8 .

\section{PEMBAHASAN}

Prevalensi Pemberian ASI Eksklusif di Kecamata Kubu, Karangasem

Setelah dilakukan penelitian mengenai frekuensi distribusi ketepatan pemberian MP ASI dengan menggunakan sampel penelitian masyarakat di wilayah kerja Puskesmas Kubu II, didapatkan pemberian ASI Eksklusif sebanyak 22 ibu (27.7\%) dari 81 ibu. Hasil penelitian ini berbeda dengan data yang didapat dari program gizi puskesmas kubu II yang menyatakan keberhasilan ASI Eksklusif adalah $61.45 \%$. Perbedaan hasil dari penelitian dengan data puskesmas Kubu II dapat disebabkan oleh beberapa hal, yakni data pada puskesmas mencari tingkat pemberian ASI Eksklusif semenjak umur bayi berusia 1 bulan, sedangkan pada penelitian ini, sampel diambil dari umur 6-24 bulan. Besar kemungkinan perbedaan hasil prevalensi pemberian ASI Eksklusif dikarenakan banyak bayi berusia dibawah 6 bulan juga diikutsertakan dalam data puskesmas kubu II. Pada penelitian ini juga didapatkan bahwa sebagian besar bayi mulai diberikan MP ASI pada usia 3 bulan sebanyak 21 bayi (25.9\%). Disisi lain, penelitian ini hanya dilakukan pada 5 posyandu yang ada dalam lingkup kerja Puskesmas Kubu II dari total 75 posyandu, sehingga jumlah sampel tidak terlalu besar.

Dari hasil penelitian ini, prevalensi pemberian ASI Eksklusif di kecamatan Kubu II masih lebih baik dibandingkan hasil RISKESDAS tahun 2010, dimana hanya terdapat $15.3 \%$ ibu yang memberikan ASI Eksklusif pada bayinya hingga umur 6 bulan.

Di wilayah kerja puskesmas kubu II, kebanyakan MP ASI yang diberikan pertama kali berupa bubur susu (88.9\%). Hal ini sama dengan penelitian Manulu (2008) bahwa sebagian besar (92.68\%) telah mendapatkan makanan tambahan berupa bubur susu. ${ }^{7}$ Dalam penelitian ini juga didapatkan pada usia 6-24 bulan diketahui frekuensi pemberian MP ASI paling banyak 3 kali sehari (82.7\%). Hal ini sesuai dengan anjuran kemenkes RI yaitu peningkatan pemberian MP ASI dari 2-3 kali sehari menjadi 3-5 kali sehari setelah usia 12 bulan hingga usia 24 bulan.

Dari segi alasan pemberian jenis MP ASI, didapatkan alasan mudah diperoleh/praktis sebesar 50 orang $(61.7 \%)$. Hal ini sesuai dengan penelitian yang dilakukan oleh Laksmi (2013) dengan persentase alasan praktis/mudah sebesar $31.6 \%{ }^{7}$ 


\section{Prevalensi Kejadian Gizi Kurang di Kecamatan Kubu, Karangasem.}

Dalam penelitian ini, 81 sampel di wilayah puskesmas Kubu II diketahui tidak ada bayi yang mengalami gizi buruk atau gizi lebih, sebesar $1.2 \%$ bayi berstatus gizi kurang, dan $99.8 \%$ bersatatus gizi baik. Hasil ini sesuai dengandengan data dari puskesmas Kubu II dimana terdapat $1.14 \%$ kasus gizi kurang dan gizi buruk bayi usia 6-24 bulan pada penimbangan bulan maret 2014. Sedikit perbedaan terjadi dapat dikarenakan beberapa hal seperti perbedaan jumlah sampel, usia bayi, waktu pengambilan data, serta perbedaan sampel yang berarti perbedaan tingkat pendidikan, penghasilan, pekerjaan orang tua yang mempengaruhi status gizi bayi.Prevalensi kejadian gizi kurang di kecamatan Kubu II masih lebih baik dibanding prevalensi kejadian gizi kurang nasional menurut RISKESDAS 2013 yang setinggi $19.4 \%$, dan juga sudah memenuhi target MDG 2015 sebesar 15.5\%.

\section{Distribusi Tingkat Pendidikan Terhadap Ketepatan Pemberian MP ASI}

Tingkat pendidikan merupakan salah satu komponen penting untuk meningkatkan praktek pemberian makanan pendamping ASI. Hasil penelitian ini mendapatkan karakteristik dari ibu sebagian besar berpendidikan rendah sebanyak 59 orang $(72.8 \%)$, pendidikan menengah 16 orang (19.8\%) dan pendidikan tinggi 6 orang (7.4\%). Tingkat pendidikan ini kemudian akan terkait dengan pengetahuan ibu terhadap MP ASI. Berdasarkan beberapa penelitian tentang pengetahuan ibu berdasarkan pendidikan terhadap praktek pemberian makanan pendamping ASI, didapatkan hasil yang berbeda beda.

Berdasarkan hasil penelitian diketahui bahwa responden dengan tingkat pendidikan rendah mayoritas memberikan makanan pendamping ASI tidak tepat waktu. Dapat dilihat pada tabel 5.7 bahwa tren yang terjadi adalah semakin rendah tingkat pendidikan ibu, semakin tinggi pemberian MP ASI tidak tepat waktu. Dari 59 ibu yang berpendidikan rendah, sebanyak 52 ibu (88.1\%) memberikan MP ASI tidak tepat waktu. Hal ini sesuai dengan penelitian dari Daulat Ginting (2013) dimana ibu yang tingkat pendidikannya rendah cenderung memberikan MP ASI Dini (72.4\%). ${ }^{8}$ Pada penelitian yang dilakukan oleh Setyaningsih (2010) juga didapatkan ibu dengan pendidikan rendah memberikan MP ASI tidak tepat waktu sebesar $75 \%{ }^{9}$

\section{Distribusi Ketepatan Pemberian MP ASI Terhadap Status Gizi Bayi}

Ketepatan waktu pemberian MP ASI merupakan salah satu faktor yang berpengaruh terhadap status gizi bayi. Pada bayi yang diberikan MP ASI tidak tepat waktu, baik MP ASI dini maupun MP ASI terlambat dapat menyebabkan perbedaan status gizi. MP ASI dini maupun terlambat akan menyebabkan bayi rentan mengalami penyakit infeksi, alergi, kekurangan gizi, dan kelebihan gizi , sehingga dapat menyebabkan malnutrisi dan gangguan pertumbuhan.Secara fisik anak yang menderita gizi kurang dan gizi buruk akan mengalami gangguan pertumbuhan dan mudah terkena penyakit infeksi. Penyebab gangguan pertumbuhan usia muda diantaranya disebabkan karena ketepatan pemberian makanan pendamping ASI (MP - ASI ) yang kurang tepat. Pada penelitian ini dilihat dari ketepatan waktu pemberian MP - ASI dengan status gizi bayi, dapat digambarkan bahwa 1 bayi (1.7\%) yang tidak tepat waktu pemberian MP ASIberstatus gizi kurang dan 58 bayi (98.3\%) yang tidak tepat waktu pemberian MP ASIberstatus gizi baik. Selain itu pada bayi dengan pemberian MP ASI tepat waktu seluruhnya berstatus gizi baik sebanyak 22 bayi (100\%).Hasil penelitian ini sejalan dengan hasil penelitian Hadiyat Miko (2003) yang menyatakan bahwa bayi yang tidak tepat pemberian MP ASI lebih berisiko menderita gizi kurang dibanding bayi yang mendapatkan ASI eksklusif penelitian tersebut dilakukan di Kabupaten Tasikmalaya Jawa Barat. ${ }^{10}$

Kasus gizi kurang ditemukan pada pemberian MP ASI tidak tepat waktu dapat dikarenakan dipengaruhi oleh beberapa hal, antara lain gangguan menyusui, terjadinya kasus infeksi, resiko diare, fungsi usus belum berkembang dengan baik dan alergi terhadap makanan. ${ }^{7}$ Pada penelitian ini hanya 1 kasus gizi 
kurang yang ditemukan pada sampel, hal ini dapat disebabkan karena kecilnya jumlah sampel. Pada teori, pemberian MP ASI dini dapat menyebabkan baik terjadi gizi kurang maupun gizi lebih, namun pada penelitian ini tidak ditemukan adanya kasus gizi lebih. Hal ini dapat dipengaruhi oleh beberapa variabel lain yang tidak diteliti dalam penelitian ini seperti pola pengasuhan bayi, paritas, usia terakhir pemberian ASI, status kesehatan terakhir, riwayat infeksi dan lainnya. Kebiasaan masyarakat di Kecamatan Kubu II yang memberikan ASI hingga usia 2 tahun dapat menyuplai gizi yang adekuat meskipun telah diberikan MP ASI secara tidak tepat waktu sehingga gizi bayi menjadi baik.

\section{KESIMPULAN DAN SARAN}

\section{Simpulan}

Dari hasil penelitian ini dapat ditarik simpulan yaitu: prevalensi ASI Eksklusif di Kecamatan Kubu II adalah sebesar $27.7 \%$, masih dibawah target puskesmas sebesar $80 \%$ namun berada diatas prevalensi nasional sebesar $15.3 \%$. Prevalensi bayi usia 6-24 bulan dengan status gizi kurang di Kecamatan Kubu II adalah sebesar 1.7\%.Tren yang dapat dilihat dari tingkat pendidikan ibu terhadap ketepatan waktu pemberian MP ASI adalah semakin rendah tingkat pendidikan ibu semakin tinggi pemberian MP ASI tidak tepat waktu.Pada bayi yang diberikan MP ASI tidak tepat waktu ditemukan 1 kasus gizi kurang, sedangkan pada MP ASI tepat waktu seluruhnya berstatus gizi baik.

\section{Saran}

Saran yang dapat diberikan dari penelitian ini, yaitu: perlu dilakukan penyuluhan pada orang tua balita di wilayah kerja Puskesmas Kubu II dengan lebih meningkatkan program gizi di Puskesmas tersebut, utamanya penyuluhan mengenai pentingnya pemberian ASI Eksklusif dan pemberian MP ASI. Perlu dilakukan penelitian lebih lanjut untuk mengetahui gambaran pemberian ASI Eksklusif, MP
ASI dan status gizi pada bayi di wilayah kerja puskesmas Kubu II, sehingga kedepannya prevalensi pemberian ASI Eksklusif, MP Asi tepat waktu bisa lebih baik dan status gizi kurang maupun buruk dapat di tanggulangi.

\section{DAFTAR PUSTAKA}

1. Waryana. (2010). Gizi Reproduksi. Yogyakarta: Pustaka Rihama.

2. Djitowiyono, S., W. (2010). Asuhan Keperawatan Neonatus dan Anak. Yogyakarta : Nuha Medika

3. Depkes RI.( 2006). Pedoman Umum Pemberian Makanan Pendamping ASI lokal. Depkes RI : Bakti Husada.

4. Indiarti (2008). Faktor-faktor yang beghubungan dengan pemberian MP-ASI dini pada bayi usia 06 bulan. http://eprint.undip.ac.id/24933/diakes5 Juni 2014.

5. Susanty, S. Dkk. (2012). Hubungan Pola Pemberian ASI dan MP-ASI dengan Gizi Buruk pada Anak Usia 6-24 Bulan di Kelurahan Pannampu. Makasar.

6. Dinas Kesehatan Provinsi Bali (2013). Profil Kesehatan Provinsi Bali 2012. Bali 2013.

7. Manalu, A (2008). Pola Makan dan Penyapihan Serta Hubungan dengan Status Gizi Balita di Kecamatan Silima Pungga-pungga Kabupaten Dairi. Sumatera Utara.

8. Daulat G, dkk. 2009. Pengaruh Karakteristik, Faktor Internal dan Eksternal Ibu terhadap pemberian MP-ASI Dini pada Bayi Usia <6 Bulan di Wilayah Kerja Puskesmas Barusjahe Kabupaten Karo Provinsi Sumatera Utara

9. Setyaningsih, dkk. (2009). Perilaku Ibu dalam Pemberian Makanan Tambahan pada Bayi Usia Kurang dari Enam Bulan di Kelurahan Mangga Perumnas Simalingkir Medan. Fakultas Keperawatan USU.

10. Miko H, dkk.2008. Analisis Pola Asuh Makan dan Status Gizi Pada Bayi di Kelurahan PB Selayang Medan 